\title{
Stock Market Development and Economic Growth in India: An Empirical Analysis
}

\author{
Srinivasan Palamalai ${ }^{\mathrm{a}}$, Karthigai Prakasam ${ }^{\mathrm{b}}$ \\ ${ }^{a}$ Assistant Professor, Xavier Institute of Management \& Entrepreneurship, Electronics City, Bangalore, Karnataka, India. \\ ${ }^{b}$ Assistant Professor, Department of Commerce, Christ University, Bangalore, Karnataka, India
}

\begin{abstract}
The link between stock market development and economic activity has always been the subject of considerable debate in the field of economics and it raises empirical question whether stock market development influences economic activity or whether it is a consequence of increased economic activity. This study attempts to investigate the direction of causality between stock market development and economic growth in the Indian context. Using the cointegration and causality tests for the period June 1991 to June 2013, the study confirms a well defined long-run equilibrium relationship between the stock market development indicators and economic growth in India. The empirical results show bidirectional causality between market capitalisation and economic growth and unidirectional causality from turnover ratio to economic growth in the long-run and short-run. By and large, it can be inferred that the stock market development indicators viz. market capitalisation and turnover ratio have a positive influence on economic growth in India.
\end{abstract}

Keywords: Stock Market Development, Cointegration, Granger Causality, Economic Growth.

JEL code: C22; E44; O16

CC 2014 Published by SSBFNET

\section{Introduction}

The Indian financial sector has undergone a significant structural transformation since the initiation of the economic reforms in 1990's. Financial sector reforms mainly entailed reforms of the banking system and the capital market. As a result of reforms since 1991, the financial markets have transited to a regime of market-determined interest and exchange rates, current account convertibility, phased capital account liberalization and an auction based system in the government securities market. Policy initiatives have tried to ensure financial stability, curbing excessive fluctuations and volatility in interest rates, exchange rates and hence moderating inflation without choking credit to productive sectors, thus mitigating risks arising out of deregulation and globalization of financial markets and helping in the efficient allocation of resources in the real sectors of the economy. Most importantly, the capital market reform was an integral part of the agenda of financial sector reforms in India. Gupta (2002) has rightly pointed out that improving stock market efficiency, enhancing transparency, checking unfair trade practices and bringing the Indian capital market up to a certain international standard are some of the major objectives of the capital market reforms. Due to this reforming process, the Securities and Exchange Board of India (SEBI) was formed as the apex regulator of the

\footnotetext{
${ }^{\mathrm{a}}$ Corresponding author.
} 
capital market. The new regulatory framework laid down by SEBI sought to strengthen investor protection by ensuring disclosure and transparency rather than through direct controls. The SEBI has apparently made progress in achieving its major objectives such as to protect the interests of investors in securities and to promote the development of, and to regulate, the securities market and for matters connected therewith or incidental thereto.

Following the implementation of reforms in the securities industry in the post liberalisation period, Indian stock markets have grown significantly in terms of market capitalization and market turnover ratio. As per Standard \& Poor's Global Stock Markets Factbook (2011), India ranked $7^{\text {th }}$ in terms of market capitalization $\left(11^{\text {th }}\right.$ in 2009$)$, 10 ${ }^{\text {th }}$ in terms of total value traded in stock exchanges, and $22^{\text {nd }}$ in terms of turnover ratio, as of December 2010. The market capitalization in Indian stock markets has grown over the period, indicating that more companies are using the trading platform of the stock exchange. The market capitalization across India was around Rs. 68,430,493 million at the end of March 2011. During 2010, turnover of Indian stock exchanges in the cash segment increased 43.3 percent to Rs. 55,184.7 billion from Rs. 38,525.8 billion in 2009. The Bombay Stock Exchange (BSE) and National Stock Exchange (NSE) together contributed 99.9 percent of the turnover. Of this, the NSE accounted for 74.9 percent of the total turnover in the cash market whereas the BSE accounted for 24.9 percent to the total. During 2012-13, Indian equity markets staged a slow recovery followed by significant turnaround amidst strong headwinds caused due to strains in global financial markets coupled with lingering domestic economic woes. Markets recovered in the backdrop of strong revitalizing policy announcement and reforms which induced investor optimism and energized the investment milieu. The much needed liquidity for the markets was delivered by the enhanced foreign capital flows in search of higher returns. In spite of the macroeconomic stress, investor confidence and market sentiment remained firm on the expectations of further improvement in the domestic economic scenario.

Despite the substantial growth in India's financial sector, the trend of economic growth is seems to be positive over the last two decades. The growth rate is almost 6.2 percent per annum during 1994-95. The trend was slightly decelerated to 3.8 percent in 2002 and then increased to 9.7 percent in 2006-07. However, the year 2009 saw a significant slowdown in India's GDP growth rate to 6.7 percent (Economic Survey, 2008-09). This is probably due to global financial crisis in 2007-2008. The deceleration of growth in 2008-09 was spread across all sectors except mining, quarrying, community, social and personal services. This could be concluded that the performance of economic growth depends upon the growth of financial sectors in the economy.

Most importantly, it is widely recognized that the development of the stock market is considered crucial to national economic growth as it: (a) provides an additional channel for encouraging and mobilising domestic savings; (b) ensures improvements in the productivity of investment through allocation of capital/resources; and (c) increases managerial discipline through the market for corporate control. The stock market positively influences national savings, allocation of capital/resources, financing funds and incentives for corporates, and finally paves the way to economic growth. Taking into account the importance of stock market in the process of economic development, the stock market development has a causal influence on economic growth. That is, deliberate creation of financial institutions and markets increases the supply of financial services. The capital market increases savings, and allocates 
them to more productive investments. Thereby stock market development can stimulate economic growth. This is known as 'supply leading' hypothesis. For example, findings in McKinnon (1973), Shaw (1973), and King and Levine (1993a, 1993b) support this hypothesis.

On the other hand, there exists a causal relationship from economic growth to stock market development, i.e., 'demand following' hypothesis. In this view, stock market development appears as a consequence of the economic development. Continual economic expansion requires more financial services and new instruments. The financial system adapts itself to the financing needs of the real sector and fits in with its autonomous development. Therefore, this type of stock market development plays a rather passive role in the growth process. For example, Gurley and Shaw (1967), Goldsmith (1969) and Jung (1986) show that, economic growth propels financial development, supporting the 'demand following' hypothesis.

Moreover, the third view stresses the reciprocal relationship between stock market development and economic growth. Economic growth makes the development of financial intermediation system profitable, and the establishment of an efficient capital market system permits faster economic growth. By specializing in fund pooling, risk diversification and liquidity management, the capital market system improves the efficiency of capital allocation and increases the productive capacity of the real sector. At the same time, the technological efficiency of the stock markets increases with its size, because economies of scale and learning-by-doing effects are present in financial intermediation activities. As a result, the real sector can exert a positive externality on the capital market through the volume of savings. Therefore, stock market development and economic growth positively influence each other in the process of development.

The above theoretical arguments primarily revolved around two major empirical questions: first whether there is a casual relationship between development of stock market and economic growth. Second, what could be the nature and direction of the causal relationship between stock market development and economic growth? Various researchers and policy makers alike have focused to understand the various ways in which economic growth can be enhanced. The relevance of policy implications pertaining to stock market development and growth nexus becomes an important substance among academics, policy makers and economists in India. If the Indian stock market acts as an engine for economic growth, then the market regulators and economic policy makers should focus their attention towards establishing and sustaining a dynamic capital market in order to foster a sound and continued economic growth. On the other hand, if economic growth leads to capital market development, then much concentration to be needed towards countries' sustained growth performance in order to enhance the development of capital markets in the economy. In this backdrop, the present study attempts to examine the causal linkage between the stock market development and economic growth in India. The rest of the paper is organized as follows: Section 2 provides the review of related literature pertaining to linkages between stock market development and economic growth. Section 3 describes the data and methodology applied in the study. Section 4 provides the empirical results and discussion followed by the concluding remarks is depicted in Section 5. 


\section{Literature Review}

The debate on whether or not financial markets promote economic growth has been an interesting topic that has prompted tremendous empirical studies to be carried out on this subject. Pardy (1992) in his seminal work has argued that in less developed countries capital markets are able to mobilize domestic savings and allocate funds more efficiently. Spears (1991) reported that in the early stages of development, financial intermediation induced economic growth. Similarly, Atje and Jovanic (1993) concluded that stock markets have long-run impacts on economic growth and it was also found that stock markets manipulate economic growth through a number of channels that are liquidity, risk diversifications, acquisition of information about firms, corporate governance and savings mobilization. Demirguc-Kunt (1994) and Levine and Zervos (1996) have supported the view that stock markets promote economic growth. With well-functional financial sector or banking sector, stock markets can give a big boost to economic development (Rousseau and Wachtel 2000, Beck and Levine, 2004). Levine and Zervos (1998) measured stock markets development along with different magnitude and have suggested a strong statistically significant relationship between initial stock market development and subsequent economic growth for forty-seven emerging economies. Filer, Hanousek and Campos (1999) examined stock market-growth nexus and exhibited significant causal relationship going from stock market development to economic growth, particularly for less developed countries. Chen and Wong (2004) elaborated that the nexus between stock returns and output growth and found that the rate of stock returns is a leading indicator of output growth in the case of four East Asian Countries. Similarly, Caporale, Howells Soliman (2005) examined the dynamic interactions between investment, stock market development and economic growth in Chile, Korea, Malaysia and the Philippines and found stock market development promotes economic growth in the long run. Adjasi and Biekpe (2005) found a significant positive impact of stock market development on economic growth in countries, classified as upper middle-income economies. Moreover, Vazakidis and Adamopoulos (2011) inferred that stock market development has larger effect on economic growth in the United Kingdom. Recently, Ikikii and Nzomoi (2013) found that stock markets development have had positive effect on economic growth in Kenya.

On the other hand, Singh (1997) focused his research on developing countries and investigated the role of stock markets towards long run economic growth in the 1980s and 1990s. He concluded that in developing countries, long run economic growth does not show dependency towards the stock market. A study by Harris (1997) on forty-nine countries for the period 1980-1991, found out that there is no significant relationship between stock market and economic growth. Recently, Boubakari and Jin (2010) proposed a positive links between the stock market and economic growth for some countries for which the stock market is liquid and highly active. However, the causality relationship is rejected for the countries in which the stock market is small and less liquid. Okoye and Nwisienyi (2013) found that the capital market in Nigeria has the potentials for growth inducing but has not contributed meaningfully to the economic growth of Nigeria. 
Moreover, the empirical studies showed that causality runs in both the directions i.e. economic growth causes the stock market development and vice versa (Arestis, Demetriades and Luintel 2001, Demetriades and Hussein 1996, Luintel and Khan 1999). Tuncer and Alovsat (2000) investigated the causal nexus between stock markets and economic growth for twenty countries and showed the bi-directional causation between stock market development and economic growth for the selected nations. Further, Shahbaz, Ahmed and Ali (2008) confirmed the long-run bidirectional causality between stock market development and economic growth in Pakistan. As regards to the research concerning India, Kamaiah and Biswal (2000) attempted to assess the empirical relationship between stock market development indicators and economic growth in India. They found stock market size was positively associated with economic growth. However, there was no support for the association between stock market liquidity and economic growth in India. Biswal and Veerashekharappa (2002) found that stock market development plays a significant role in the economic growth process in India. Agrawala and Tuteja (2007) confirmed a stable long run equilibrium relationship between stock market developments and economic growth. Chakraborty (2007) revealed the causality runs from growth rate of real GDP to stock market capitalization. Padhan (2007) and Paramati and Gupta (2011) exposed the bidirectional relationship between stock market development indicators and economic activity. Deb and Mukherjee (2008) and Acharya, Amanulla and Joy (2009) observed a strong causality runs from the stock market development to economic growth. Recently, Sahoo (2013) revealed that market-based indicators of financial depth have positive impact on economic development in India. However, he found no evidence of causality between market capitalization and economic development.

From the related literature, it was worth noting that empirical evidence is still inconclusive and remains ambiguous in the context of Indian capital markets. With the pace of economic reforms and the rapid integration towards the world economy followed in India, the importance of capital markets has grown significantly and has been receiving global attention, especially from sound investors. The Indian stock market has witnessed major fundamental institutional changes, resulting in drastic reduction in transaction costs and significant improvements in efficiency, transparency and safety which led the stock exchanges to do a remarkable task for the economic development of the country. Concurrently, the economic expansion through technological changes, products and services innovation in the postreforms period is expected to create a high demand for the development of stock markets. This paper attempts to examine the causal nexus between stock market development and economic growth in the Indian context. Most importantly, this study will seek to provide more effective and appropriate policy for the Indian economic planners, financial market regulators, market participants, academicians, and alike who seek to develop economic policies to best target for a sustainable economic development as well as the future direction of stock market developments.

\section{Reseach and Methodology}

Augmented Dickey-Fuller (Dickey and Fuller 1979) test was employed to infer the stationarity properties of the data series. Besides, the Autoregressive Distributed Lag Model (ARDL) bound testing approach was applied to investigate the long-run equilibrium relationship between stock market indicators and economic growth in India during the post- 
reforms era. Further, employing Toda and Yamamoto (1995) Causality test approaches, the present study investigates short-run causal nexus between stock market development and economic growth in India.

\subsection{Autoregressive Distributed Lag Model (ARDL) Bound Testing Approach}

The ARDL bounds testing approach was used to investigate the long-run equilibrium relationship among the selected time-series variables in India. The ARDL modeling approach was originally introduced by Pesaran and Shin (1999) and further extended by Pesaran, Shin and Smith (2001). This approach estimates the short and long-run components of the model simultaneously, removing problems associated with omitted variables and autocorrelation. Besides, the standard Wald or F-statistics used in the bounds test has a non-standard distribution under the null hypothesis of nocointegration relationship between the examined variables, irrespective whether the underlying variables are I(0), I(1) or fractionally integrated. Moreover, once the orders of the lags in the ARDL model have been appropriately selected, we can estimate the cointegration relationship using a simple Ordinary Least Square (OLS) method. The ARDLUnrestricted error correction model used in the present study has the following form as expressed in Equations (1-3):

$$
\begin{aligned}
& \Delta \operatorname{In} Y_{1}=\beta_{0}+\sum_{i=1}^{m} \delta_{1} \Delta \operatorname{In} Y_{2 t-i}+\sum_{i=1}^{n} \delta_{2} \Delta \operatorname{In} Y_{3 t-i}+\sum_{i=1}^{p} \delta_{3} \Delta \operatorname{In} Y_{1 t-i}+\beta_{1} \operatorname{In} Y_{1 t-i}+\beta_{2} \operatorname{In} Y_{2 t-i}+\beta_{3} \operatorname{In} Y_{3 t-i}+\varepsilon_{t} \\
& \Delta \operatorname{In} Y_{2}=\beta_{0}+\sum_{i=1}^{m} \delta_{1} \Delta \operatorname{In} Y_{1 t-i}+\sum_{i=1}^{n} \delta_{2} \Delta \operatorname{In} Y_{3 t-i}+\sum_{i=1}^{p} \delta_{3} \Delta \operatorname{In} Y_{2 t-i}+\beta_{1} \operatorname{In} Y_{1 t-i}+\beta_{2} \operatorname{In} Y_{3 t-i}+\beta_{3} \operatorname{In} Y_{2 t-i}+\varepsilon_{t} \\
& \Delta \operatorname{In} Y_{3}=\beta_{0}+\sum_{i=1}^{m} \delta_{1} \Delta \operatorname{In} Y_{1 t-i}+\sum_{i=1}^{n} \delta_{2} \Delta \operatorname{In} Y_{2 t-i}+\sum_{i=1}^{p} \delta_{3} \Delta \operatorname{In} Y_{3 t-i}+\beta_{1} \operatorname{In} Y_{1 t-i}+\beta_{2} \operatorname{In} Y_{2 t-i}+\beta_{3} \operatorname{In} Y_{3 t-i}+\varepsilon_{t}
\end{aligned}
$$

where, $\mathrm{Y}_{1}, \mathrm{Y}_{2}$ and $\mathrm{Y}_{3}$ represents selected time series variables for the study such as Stock Market Capitalisation (MC), Stock Market Turnover Ratio (TR) and Index of Industrial Production (IIP), respectively. $\mathrm{t}$ is the time dimension and $\Delta$ denotes a first difference operator; $\beta_{0}$ is an intercept and $\varepsilon_{t}$ is a white noise error term.

The first step in the ARDL bounds testing approach is to estimate Equations (1-4) using ordinary least squares method in order to test for existence of a long-run relationship among the variables by conducting an F-test for the joint significance of the coefficients of the lagged level variables, i.e., $H_{0}: \beta_{1}=\beta_{2}=\beta_{3}=0$ against the alternative $H_{1}: \beta_{1} \neq \beta_{2} \neq$ $\beta_{3} \neq 0$, which normalize on $\mathrm{Y}_{1}$ by $\mathrm{F}\left(\mathrm{Y}_{1} / \mathrm{Y}_{2}, \mathrm{Y}_{3}\right), \mathrm{Y}_{2}$ by $\mathrm{F}\left(\mathrm{Y}_{2} / \mathrm{Y}_{1}, \mathrm{Y}_{3}\right)$ and $\mathrm{Y}_{3}$ by $\mathrm{F}\left(\mathrm{Y}_{3} / \mathrm{Y}_{1}, \mathrm{Y}_{2}\right)$, respectively. Two sets of critical value bounds for the F-statistic are generated by Pesaran, Shin and Smith (2001). If the computed F-statistic falls below the lower bound critical value, the null hypothesis of no cointegration cannot be rejected. Contrary, if the computed F-statistic lies above the upper bound critical value; the null hypothesis is rejected, implying that there is a long-run cointegration relationship amongst the variables in the model. Nevertheless, if the calculated value falls within the bounds, inference is inconclusive.

\subsection{Vector Error Correction Model}

The Vector Error Correction Model (VECM) was employed to investigate the temporal causality between stock market development and economic growth in India during the post-reforms period. The Granger Representation Theorem (Engle and Granger, 1987) states that if a set of variables is cointegrated, then there exists a valid error 
correction representation of the data, in which the short-term dynamics of the variables in this system are influenced by the deviation from long-term equilibrium. In a VECM, short-term causal effects are indicated by changes in other differenced explanatory variables and the long-term relationship is implied by the level of disequilibrium in the cointegration relationship, i.e., the lagged error correction term (ECT). Hence, the Vector Error Correction model is useful for detecting short- and long-term Granger causality tests (Granger, 1969). The causal nexus between selected time-series variables was investigated by estimating the following Vector Error Correction Model (VECM) (Johansen, 1988 and Johansen and Juselius, 1990):

$\Delta Y_{l t}=\mu_{l}+\gamma_{l} z_{t-1}+\sum_{\mathrm{i}=1}^{\mathrm{p}-1} \theta_{l i} \Delta Y_{l t-i}+\sum_{\mathrm{i}=1}^{\mathrm{p}-1} \delta_{l i} \Delta Y_{2 t-i}+\varepsilon_{l t}$

$\Delta Y_{2 t}=\mu_{2}+\gamma_{2} z_{t-1}+\sum_{\mathrm{i}=1}^{\mathrm{p}-1} \theta_{2 i} \Delta Y_{I t-i}+\sum_{\mathrm{i}=1}^{\mathrm{p}-1} \delta_{2 i} \Delta Y_{2 t-i}+\varepsilon_{1 t}$

where, $Y_{1}$ and $Y_{2}$ represents the stock market development indicators, viz. market capitalization and stock market turnover ratio and index of industrial production, respectively. $\gamma^{\prime} \mathrm{z}_{\mathrm{t}-1}$ is the error correction term derived from the cointegrating vector. $\theta$ and $\mho$ are the short-run parameters to be estimated, $\mathrm{p}$ is the lag length, and $\varepsilon_{\mathrm{t}}$ are assumed to be stationary random processes with a mean of zero and constant variance.

For each equation in the VEC Model, we employ short-term Granger causality to test whether endogenous variables can be treated as exogenous by the joint significance of the coefficients of each of the other lagged endogenous variables in that equation. The short-term significance of sum of the each lagged explanatory variables ( $\theta$ 's and $\sigma$ 's) can be exposed either through joint $\mathrm{F}$ or Wald $\chi^{2}$ test. Besides, the long-term causality is implied by the significance of the t-tests of the lagged error correction term $\left(\mathrm{z}_{\mathrm{t}-1}\left(\mathrm{ECT}_{\mathrm{t}-1}\right)\right)$. However, the non-significance of both the $\mathrm{t}$-statistics and joint $\mathrm{F}$ or Wald $\chi^{2}$ tests in the Vector Error Correction Model indicates econometric exogeneity of the dependent variable.

\subsection{Toda and Yamamoto Version of Granger Causality}

Turning to methodology, we note that causality is meant in the Granger (1969) sense; that is, the purpose is to find out whether one variable precedes another variable. For this purpose, the following vector autoregressive model of order p, $\operatorname{VAR}(p)$, is utilized:

$$
y_{t}=v+A_{1} y_{t-1}+\ldots+A_{p} y_{t-p}+\varepsilon_{t}
$$

with $y_{t}$ being the integrated and possible cointegrated variables, $v$ the vector of intercepts, $A_{i}$ the vector parameter for lag $\mathrm{i}(i=1, \ldots, p)$ and $\varepsilon_{t}$ the vector of error terms. It is well known in the econometric literature that if the variables are integrated, asymptotical distributions cannot be used to test for restrictions in the VAR. In particular, 
Wald tests for Granger causality are known to result in non-standard limiting distributions depending on the cointegration properties of the system and, possibly, in nuisance parameters (Toda and Phillips, 1993). In order to find a solution to this problem, Toda and Yamamoto (1995) and Dolado and Lütkepohl (1996) proposed the following augmented VAR models in order to test causality if the variables are integrated and if the assumption of normality of the error term vector is fulfilled.

$y_{t}=v+A_{1} y_{t-1}+\ldots+A_{p} y_{t-p}+\ldots+A_{p+d} y_{t-p-d}+\varepsilon_{t}$

where, $\mathrm{d}$ is equal to the integration order of the variables involved in the VAR system. The $\mathrm{k}^{\text {th }}$ element of $y_{t}$ does not Granger-cause the $\mathrm{j}^{\text {th }}$ element of $y_{t}$ if the following hypothesis is not rejected at a given level of significance;

$\mathrm{H}_{0}$ : the row $\mathrm{j}$, column k element in $A_{i}$ equals zero for $i=1, \ldots, p$

Hence, the Toda and Yamamoto Distributed Lag (TYDL) procedure consists on over-fit a level VAR specification with a total of $\mathrm{p}=(\mathrm{k}+\mathrm{dmax})$ lags where $\mathrm{k}$ is the lag-length chosen by using some information criteria and dmax is the maximal order of integration for the time series data involved in the system. The asymptotic chi-squared distributed MWALD test proposed is applied to the first k VAR coefficient matrix while the coefficient matrices of the last dmax lagged vectors in the model are ignored. More precisely, the underlying intuition of this approach to Granger causality is that whenever the elements in at least one of the coefficient matrices $A_{i}$ are not restricted at all under the null hypothesis (for instance, the non causality restriction which is involved in a VAR modelling elements from all $A_{i}$, $i=1, \ldots, k)$ it is enough to add extra and redundant lags in estimating the parameters of the structure to ensure the standard asymptotic properties of the Wald statistic which maintains its usual limiting $\chi^{2}$ distribution. The test has to be performed on the $A_{i}, i=1, \ldots, k$ only with the last redundant lags ignored. Therefore, the TYDL procedure enables the proposed MWALD statistic to test linear or nonlinear restrictions on these $\mathrm{k}$ coefficient matrices using the standard asymptotic theory. At this point it is essential to note that the TYDL procedure does not call for pre-testing unit roots and cointegration before causality, testing avoiding results that may suffer from size distortions and inference biases leading to an over-rejection of the non-causal null hypothesis. Of course, there may be a loss of power due to over-specifying the lag length. The loss in power may not be substantial if the true order $p$ is large and the dimension $\mathrm{k}$ is small or moderate because of the relative reduction in the estimation precision due to one extra lag.

The Toda and Yamamoto (1995) augmented Granger causality test has been obtained in the present study by estimating the following VAR model: 


$$
\begin{aligned}
& \operatorname{LSD}_{\mathrm{t}}=\mathrm{a}_{1}+\sum_{\mathrm{j}=1}^{\mathrm{n}} \mathrm{b}_{1 \mathrm{j}} \operatorname{LSD}_{\mathrm{t}-\mathrm{j}}+\sum_{\mathrm{j}=1}^{\mathrm{n}} \mathrm{c}_{1 \mathrm{j}} \operatorname{LIIP}_{\mathrm{t}-\mathrm{j}}+\mathrm{u}_{1 t} \\
& \operatorname{LIIP}_{\mathrm{t}}=\mathrm{a}_{2}+\sum_{\mathrm{j}=1}^{\mathrm{n}} \mathrm{b}_{2 \mathrm{j}} \operatorname{IIP}_{\mathrm{t}-\mathrm{j}}+\sum_{\mathrm{j}=1}^{\mathrm{n}} \mathrm{c}_{2 \mathrm{j}} \operatorname{LSD}_{\mathrm{t}-\mathrm{j}}+\mathrm{u}_{2 t}
\end{aligned}
$$

where, LSD and LIIP represents the log of stock market development indicators, viz. market capitalization and stock market turnover ratio and $\log$ of index of industrial production (IIP), respectively.

\subsection{Impulse Response Function}

Finally, the study applied Impulse Response Functions (IRFs) to produce the time path of the dependent variables in the VAR, to shocks from all the explanatory variables. If the system of equations is stable any shock should decline to zero, an unstable system would produce an explosive time path. Impulse response analysis traces out the responsiveness of the dependent variable in VAR to shocks to each of the other explanatory variables over the period of time. A shock to a variable in a VAR framework not only directly affects that variable, but also transmits its effect to all other endogenous variables in the system.

The present study depends on monthly data that ranges from June 1991 to June 2013. The data on stock market development was measured by two proxies, viz. market capitalization as a percent of IIP and turnover ratio, which is the value of total traded shares expressed as a percentage of total market capitalization. The former variable shows the overall size of the stock market as a percentage of IIP at constant price. Market capitalization equals the value of listed domestic shares on domestic exchanges divided by IIP. The assumption behind this measure is that overall market size is positively correlated with the ability to mobilize capital and diversify risk on an economy-wide basis (Levine and Zervos, 1996). The latter variable i.e. turnover ratio was used as a measure of liquidity. It equals the value of total domestic shares traded on domestic exchanges divided by the market capitalization. A high value for total value traded may result from high trading activity in certain active stocks, while there may also be a significant number of relatively inactive shares listed on the same stock exchange. In this case, a better indicator of stock market activity is the turnover ratio. Specifically, turnover measures the volume of domestic equities traded on domestic exchanges relative to the size of the market. And finally the economic growth was measured by IIP i.e. Index of Industrial Production (as a proxy variable for economic growth). All the necessary information for the study was collected from Handbook of statistics on the Indian Economy, Reserve Bank of India, Mumbai.

\section{Empirical Results}

To set the stage for the cointegration test, the order of integration of the variables is initially determined using the Augmented Dickey-Fuller (ADF) test. The testing procedures are based on the null hypothesis that a unit root exists in the autoregressive representation of the series. The unit root test results reported in Table 1 shows that index of industrial production and market capitalisation variables are non-stationary at levels and are stationary after first 
differencing, implying the first order of integration, I(1). The market turnover ratio series is found to be stationary at the level and the order of integration is zero, $\mathrm{I}(0)$.

Table 1. Augmented Dickey-Fuller (ADF) Test

\begin{tabular}{ccc}
\hline Variables & $\begin{array}{c}\text { ADF Test statistics } \\
\text { (levels) }\end{array}$ & $\begin{array}{c}\text { ADF Test statistics } \\
\text { ( } \mathbf{1}^{\text {st }} \text { difference) }\end{array}$ \\
\hline IIP & -0.917 & $-2.588 * * *$ \\
MC & -0.864 & $-16.602 *$ \\
TR & $-6.952 *$ & - \\
\hline * and *** denotes that the null hypothesis that the variable concerned is non-stationary can be rejected at one percent and ten \\
percent significance level, respectively. IIP, MC and TR represents Index of Industrial Production, Market Capitalisation and \\
Turnover ratio, respectively. \\
Source: Author's own computation.
\end{tabular}

Since the order of the stationary is I(0) and I(1), the ARDL Bounds test approach for Cointegration relationship based on equations (1-3) is applied for finding the long-run equilibrium relationship between the variables and its results are depicted in Table 2. The appropriate lag length was selected on the basis of Akaike Information Criterion (AIC) for the bounds testing approach because of its best performance in small sample (Lütkepohl, 1991). The empirical results reveal that calculated F-statistics are found to be higher than the upper bound critical value at one percent level of significance when IIP is regressed on market capitalisation and vice versa, indicating there is a stable long-run cointegration relationship between market capitalisation and IIP. Similarly, the calculated F-statistics for turnover ratio and IIP suggests that the null hypotheses of no cointegrating relationship are rejected at one percent levels, implying the existence of a level relationship (a long-run relationship) between turnover ratio and IIP and vice versa. By and large, the ARDL Cointegration test confirms a well defined long-run equilibrium relationship among the stock market development indicators and economic growth in India.

Table 2. ARDL Cointegration Bound Testing Approach

\begin{tabular}{ccc}
\hline & \multicolumn{2}{c}{ Stock Market Capitalisation and Economic Growth } \\
\hline Model Specification & F-statistics & Inference \\
\hline $\mathrm{F}_{\mathrm{MC}}(\mathrm{MC} / \mathrm{IIP})$ & $6.844^{*}$ & Cointegration \\
$\mathrm{F}_{\mathrm{IIP}}(\mathrm{IIP} / \mathrm{MC})$ & $7.490^{*}$ & Cointegration \\
\hline & Stock Market Turnover Ratio and Economic Growth \\
\hline $\mathrm{F}_{\mathrm{TR}}(\mathrm{TR} / \mathrm{IIP})$ & $8.307^{*}$ & Cointegration \\
$\mathrm{F}_{\mathrm{IIP}}(\mathrm{IIP} / \mathrm{TR})$ & $7.075^{*}$ & Cointegration \\
\hline Note: $*$ indicates computed statistic falls above the upper bound value. Asymptotic critical value bounds are obtained from Pesaran, Shin and Smith \\
(2001), p. 300; Case III: Unrestricted intercept and no trend for $k=2$. Lower bound $\mathrm{I}(0)=4.85$ and Upper bound I( 1$)=6.36$ at one percent \\
significance level. IIP, MC and TR represents Index of Industrial Production, Market Capitalisation and Turnover ratio, respectively. \\
Source: Author's own computation.
\end{tabular}

Having established the long-run relationship, the next step is to estimate a Granger causality test based on vector error correction model (VECM) and the results are presented in Table 3. The coefficients of lagged error correction term measures how the dependent variable adjusts to the previous period's deviation from long-run equilibrium. In the table 
Table 4. Granger-Causality based on Toda and Yamamoto Modified Wald test

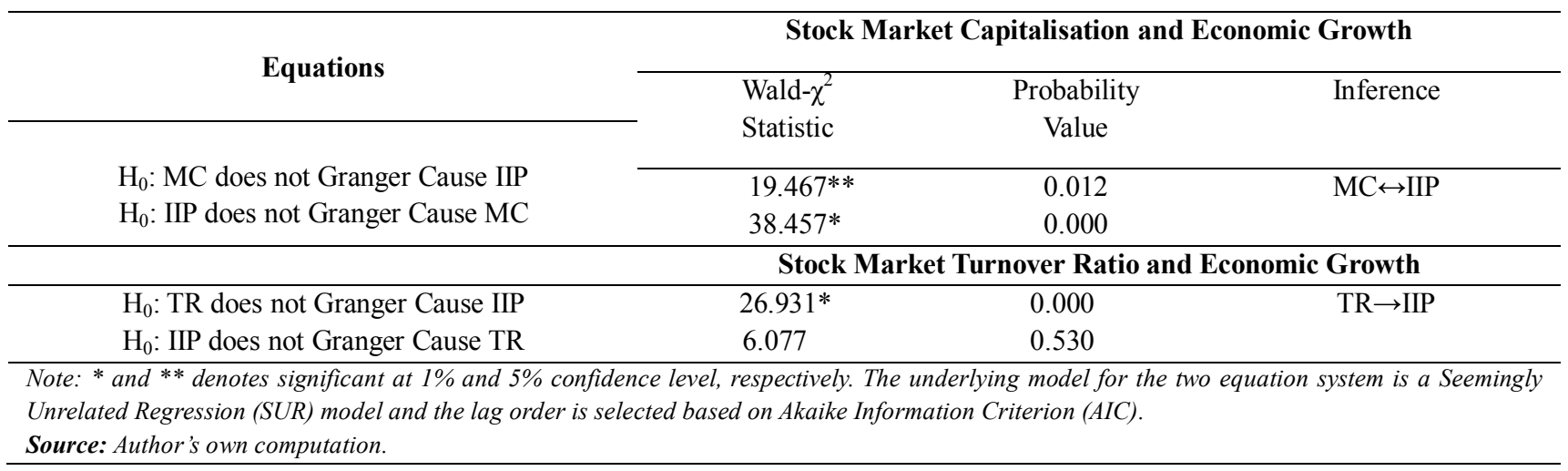

Impulse Response of IIP and turnover ratio and IIP and market capitalisation is explained by Figure 1A and 2B, respectively and are presented in the Appendix. Impulse Response of IIP and turnover ratio and IIP and market capitalisation is explained by Figure 1A and 2B, respectively. Figure 1A clearly shows that the IIP has immediate positive response to a one-standard-deviation shock in turnover ratio and the response tends to be stable in the longrun. Besides, the turnover ratio explains negative effect to a one-standard-deviation shock in IIP in the second month and found to be small and stabilized throughout the long-run horizon. This confirms the stable long-run relationship between IIP and turnover ratio in India and economic growth relatively responds more towards turnover ratio in India. Figure 1B depicts that the response of IIP to market capitalisation seem to be negative in the third month and then becomes stable throughout the time period. Besides, the market capitalisation has immediate negative response to a one-standard deviation shock in IIP and tends to show positive and stable effect throughout the proceeding months. It can be inferred that IIP and market capitalisation has a long-term relations in India. By and large, the results obtained from Figures 1A and 1B appear to be consistent with the results obtained from the cointegraton and causality tests.

By and large, the Granger-Causality based on VECM and Toda and Yamamoto Modified Wald tests result confirms bidirectional causality between market capitalization and economic growth and unidirectional causation runs from market turnover ratio and economic growth in India. It can be inferred that the stock market development indicators viz. market capitalisation and turnover ratio have a positive influence on economic growth in India. Therefore, the present study recommends that the capital market regulators should implement effective policy frameworks towards the development of Indian stock market in order to substantially enhance the size, depth and liquidity of the Indian stock market which in turn leads to increased economic activities. Further, the government should prioritize the development of the stock market through relaxing laws and of listing requirements for investors so as to encourage more market participants on the stock exchange and thus increases competition and quality of securities investments resulting in a significant influence on economic growth in India. 


\section{Conclusion}

One of the most enduring debates in economics is whether stock market development causes economic growth or whether it is a consequence of increased economic activity. The present study investigates the direction of causality between stock market development and economic growth in the Indian context. Using the cointegration and causality tests for the period June 1991 to June 2013, the study confirms a well defined long-run equilibrium relationship among the stock market development indicators and economic growth in India. Besides, the empirical results shows bidirectional causality between market capitalisation and economic growth and unidirectional causation runs from turnover ratio to economic growth in the long-run and short-run. By and large, it can be inferred that the stock market development indicators viz. market capitalisation and turnover ratio have a positive influence on economic growth in India. Therefore, the present study recommends that the capital market regulators should implement effective policy frameworks towards the development of Indian stock market in order to substantially enhance the size, depth and liquidity of the Indian stock market which in turn leads to increased economic activities. Further, the government should prioritize the development of the stock market through relaxing laws and of listing requirements for investors so as to encourage more market participants on the stock exchange and thus increases competition and quality of securities investments resulting in a significant influence on economic growth in India.

\section{References}

Acharya, D., Amanulla, S. \& Joy, S. (2009), Financial Development and Economic Growth in Indian States: An Examination, International Research Journal of Finance and Economics, 24, 117-130.

Adjasi, C. K. D. \& Biekpe, N. B. (2006), Stock Market Development and Economic Growth: The Case of Selected African Countries, African Development Review, 18, 144-161.

Agrawalla, R. K. \& Tuteja, S. K. (2007), Causality between Stock Market Development and Economic Growth: A Case Study of India, Journal of Management Research, 7, 158-168.

Arestis, P., Demetriades, P. O. \& Luintel, K. B. (2001), Financial Development and Economic Growth: The Role of Stock Markets, Journal of Money, Credit and Banking, 33, 16-41.

Atje, R. \& Jovanovic, B. (1993), Stock Markets and Development, European Economic Review, 37,632 -640.

Beck, T. \& Levine, T. (2004), Stock markets, banks, and growth: Panel evidence, Journal of Banking and Finance, $28,423-442$.

Biswal, P. C. \& Kamaiah, B., (2000), On Stock Market Development, Banks and Economic Growth in India, ISEC Working Paper No.69, Institute for Social and Economic Change, Bangalore.

Biswal, P. C. \& Veerashekarappa (2002), Stock Market Development and Economic Growth in India, Indian Journal of Economics, 82, 34-47.

Boubakari, A. A. \& Jin, D. (2010), The Role of Stock Market Development in Economic Growth: Evidence from Some Euro next Countries, International Journal of Financial Research, 1, 14-20. 
Caporale, G. M., Howells, P. \& Soliman, A. M. (2005), Endogenous Growth Models and Stock Market Development: Evidence from Four Countries, Review of Development Economics, 9, 166-176.

Chakraborty (2007), Does Financial Development cause Economic Growth? The Case of India, Occasional Paper No. 9, Institute of Development Studies, Kolkata.

Chen, L. \& Wong, A. (2004), Is Rate of Stock Returns a Leading Indicator of Output Growth? In case of Four East Asian Countries, Unpublished. In, M. Shahbaz, N. Ahmed and L. Ali (2008), Stock Market Development and Economic Growth: ARDL Causality in Pakistan, International Journal of Finance and Economics, 14: 182-195.

Deb S. G. \& Mukherjee J. (2008), Does Stock Market Development Cause Economic Growth? A Time Series Analysis for Indian Economy, International Research Journal of Finance and Economics, 21, 142-149.

Demetriades, P. O. \& Hussein, K. A. (1996), Does Financial Development Cause Economic Growth? ime-series Evidence from 16 Countries, Journal of Development Economics, 51, 387-411.

Demirguc-Kunt, A. (1994), Developing Country Capital Structure and Emerging Stock Markets, Policy Research Working Papers (Financial Policy and Systems) No. 933, World Bank, Washington, D.C.

Dickey, D. A. \& Fuller, W. A. (1979), Distribution of the Estimators for Autoregressive Time Series with a Unit Root, Journal of the American Statistical Association, 74, 427-431.

Dolado, J. J., \& Lütkepohl, H. (1996), Making Wald tests work for cointegrated VAR systems, Econometric Review, $15,369-386$.

Economic Survey (2008-09), Government of India, Ministry of Finance, New Delhi.

Engle, R. F. \& C.W.J. Granger (1987), Cointegration and Error-Correction Representation, Estimation, and Testing, Econometrica, 55, 251-276.

Filer, R. K., Hanousek, J. \& Campos, N. F. (1999), Do Stock Markets Promote Economic Growth, William Davidson Institute Working Papers Series 267, William Davidson Institute at the University of Michigan.

Goldsmith, R. W. (1969), Financial structure and development. New Haven, CT, Yale University Press.

Granger, C. W. J. (1969), Investigating causal relations by econometric models and cross- spectral methods, Econometrica, 37, 424-438.

Gupta, O. P. (2002), Effect of Introduction of Index Futures on Stock Market Volatility, The Indian Evidence, Sixth Capital Market Conference 2002, UTIICM, Mumbai.

Gurley, J., \& Shaw, E. (1967), Financial structure and economic development, Economic Development and Cultural Change, 15, 257-268.

Harris, R. (1997), Stock market and development: A re-assessment, European Economic Review, 41, 139-146.

Ikikii, M. S. \& Nzomoi, N. J. (2013), An Analysis of the Effects of Stock Market Development on Economic Growth in Kenya, International Journal of Economics and Finance, 5, 145-151.

Johansen, S. \& Juselius, K. (1990), Maximum Likelihood Estimation and Inference on Co-integration with Applications for the Demand for Money, Oxford Bulletin of Economics and Statistics, 52, 169-210.

Johansen, S. (1988), Statistical Analysis and Cointegrating Vectors, Journal of Economic Dynamics and Control, 12, 231-254. 
Jung, W. S. (1986), Financial Development and Economic Growth: International Evidence, Economic Development and Cultural Change, 34, 336-346.

King, R. \& Levine, R. (1993a), Finance and Growth: Schumpeter Might be Right, Quarterly Journal of Economics, $108,717-737$.

King, R. \& Levine, R., (1993b), Finance Entrepreneurship and Growth, Journal of Monetary Economics, 32, 513-542.

Levine, R., \& Zervos, S. (1996), Stock Market Development and Long Run Growth, The World Bank Economic Review, 10, 323-339.

Levine, R. \& Zervos, A. (1998), Stock Markets, Banks, and Economic Growth, American Economic Review, 88, 537558.

Luintel, K. B. \& Khan, M. (1999), A Quantitative Reassessment of the Finance-Growth Nexus: Evidence from a Multivariate VAR, Journal of Development Economics, 60, 381-405.

McKinnon, R. I. (1973), Money and Capital in Economic Development, Washington, D.C., Brookings Institution, pp. 177.

Okoye O. V. \& Nwisienyi J. K. (2013), The capital market contributions towards economic growth and development; the Nigerian experience, Global Advanced Research Journal of Management and Business Studies, 2, 120-125.

Padhan, P. C. (2007), The Nexus between Stock Market and Economic Activity: An Empirical Analysis for India, International Journal of Social Economics, 34, 741-753.

Paramati, S. R. \& Gupta, R. (2011), An Empirical Analysis of Stock Market Performance and Economic Growth, Evidence from India, International Research Journal of Finance and Economics, 73: 133-149.

Pardy, R, (1992), Institutional Reform in Emerging Securities Markets, Policy Research Working Papers (Financial Policy and Systems) No. 907, World Bank, Washington, D.C.

Pesaran, M. H. \& Shin Y. (1999), An Autoregressive Distributed Lag Modeling Approach to Cointegration Analysis. in Storm, S. (Ed). Econometrics and Economic Theory in the $20^{\text {th }}$ Century, The Ragnar Frish Centennial Symposium, Cambridge University Press.

Pesaran, M. H., Shin, Y. \& Smith, R. J. (2001), Bound Testing Approaches to the Analysis of Level Relationships, Journal of Applied Econometrics, 16, 289-326.

Rousseau P. L. \& Wachtel, P. (2000), Equity markets and growth: Cross country evidence on timing and outcomes, Journal of Banking and Finance, 24, 1933-1957.

Sahoo, S. (2013), Financial Structures and Economic Development in India: An Empirical Evaluation, RBI Working Paper No.02, Department of Economic and Policy Research, Reserve Bank of India, Mumbai.

Shahbaz, M., Ahmed M., \& Ali, L., (2008), Stock Market Development and Economic Growth: ARDL Causality in Pakistan, International Research Journal of Finance and Economics, 14, 182-195.

Shaw, E. (1973), Financial Deepening in Economic Development, New York: Oxford University Press.

Singh, A. (1997), Financial Liberalization, Stock Markets and Economic development, The Economic Journal, 107, 771-782. 
Spears, A. (1991), Financial Development and Economic Growth-Causality Tests, Atlantic Economic Journal, 19, 6674.

Standard \& Poors Global Stock Markets Fact book (2011), Standard \& Poors Financial Services LLC (S\&P), New York, United States.

Toda, H. Y. \& Phillips, P. C. B. (1993), Vector Autoregressions and Causality, Econometrica, 61, 1367-1393.

Toda, H. Y., \& Yamamoto, T. (1995), Statistical inference in vector autoregressive with possibly integrated processes, Journal of Econometrics, 66, 225-250.

Tuncer, G. C. \& Alovsat, M. (2000), Stock markets and economic growth: A causality test, Doğuş University Journal, 1, 124-131.

Vazakidis, A. \& Adamopoulos, A. (2010), The effect of stock and credit market development on economic growth: an empirical analysis for Italy, International Research Journal of Finance and Economics, 41, 33-42.

\section{APPENDIX}

Response to Cholesky One S.D. Innovations \pm 2 S.E.
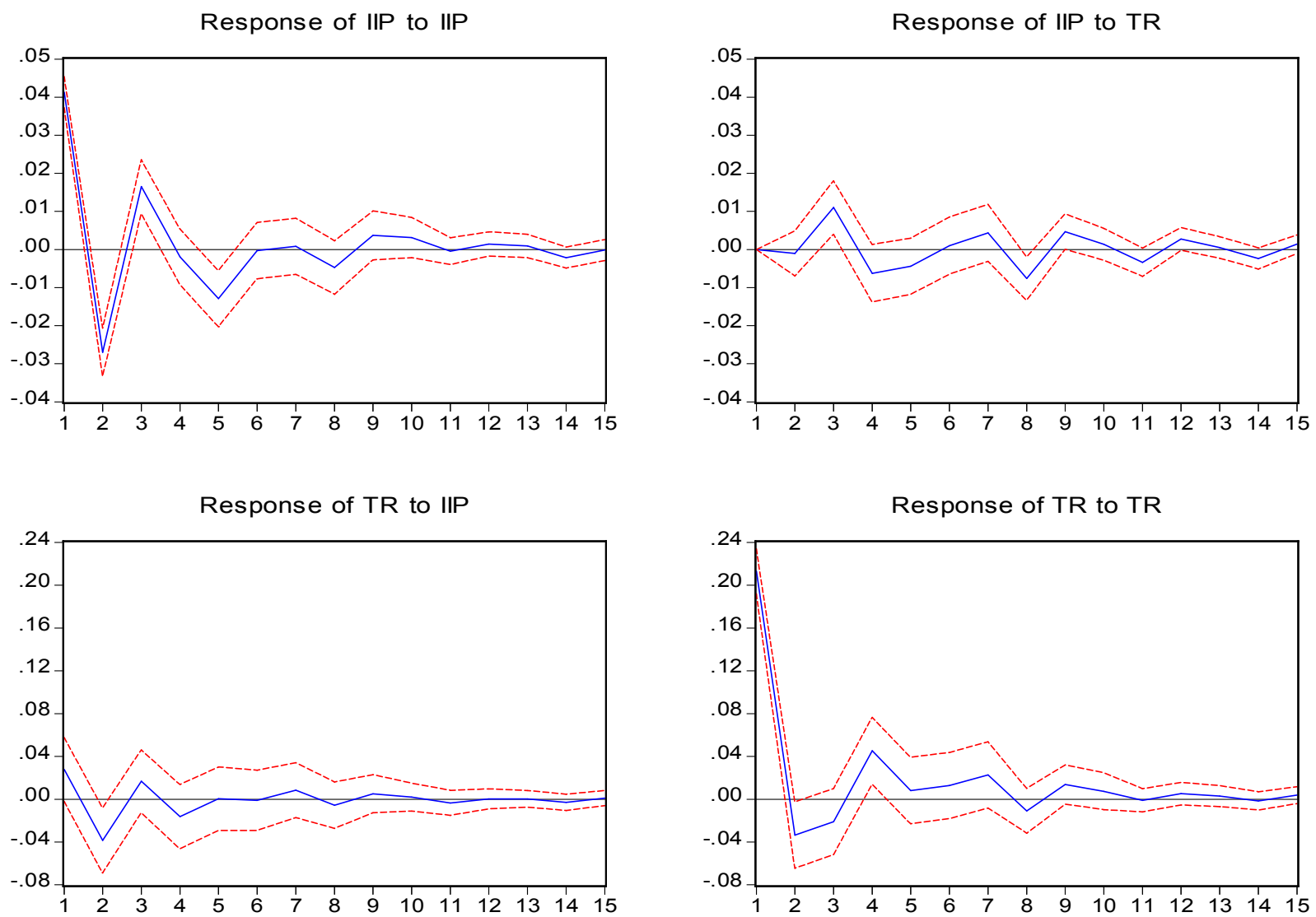

Figure-1A: Impulse Response Function of IIP and Turnover Ratio 
Response to Cholesky One S.D. Innovations \pm 2 S.E.

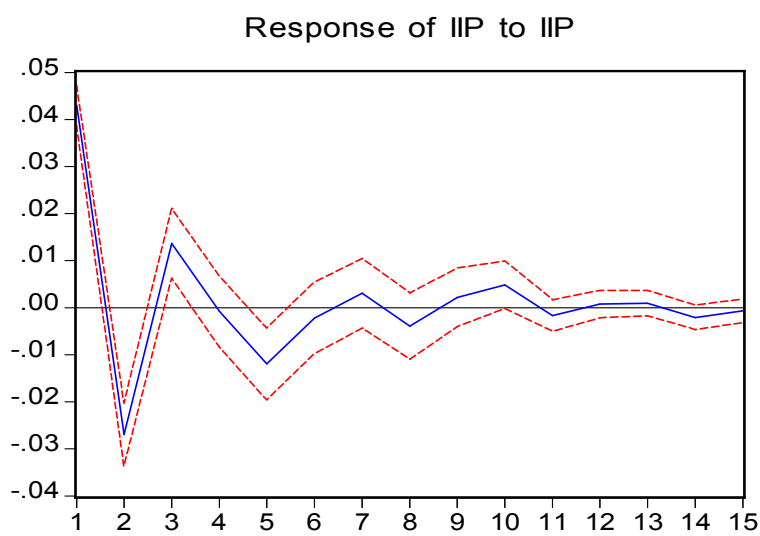

Response of IIP to MC

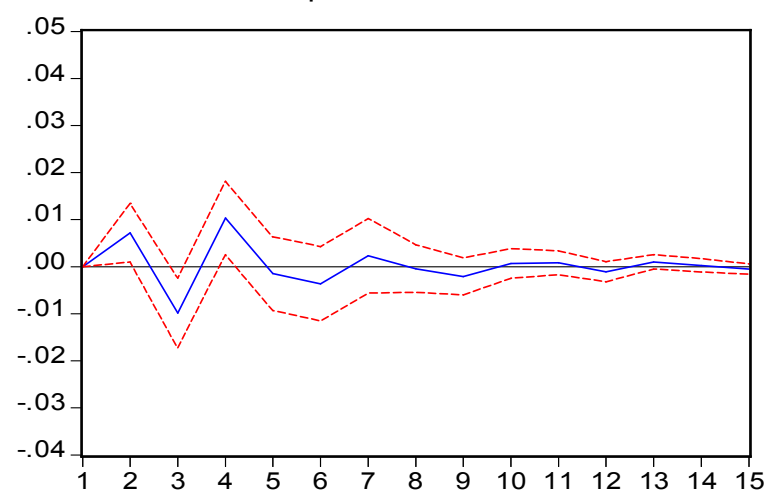

Response of MC to IIP

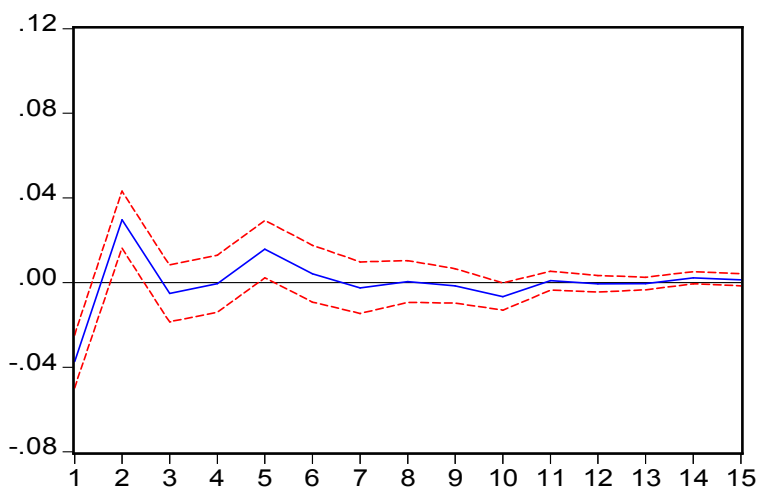

Response of $\mathrm{MC}$ to $\mathrm{MC}$

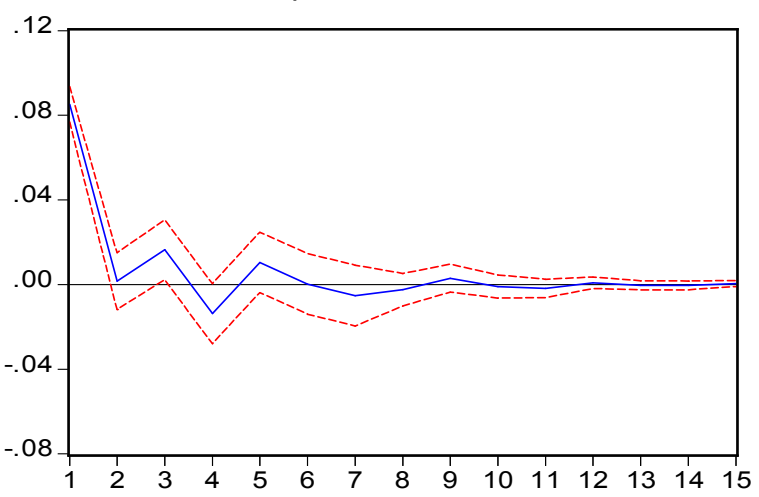

Figure-1B. Impulse Response Function of IIP and Market Capitalisation 